\title{
Antidumping Regulation and the Byrd Amendment: Does Revenue Redistribution Dissuade Dumping?
}

\author{
Rod Falvey ${ }^{\mathrm{a}^{*}}$ and Sarut Wittayarungruangsri ${ }^{\mathrm{b}}$ \\ ${ }^{a}$ University of Nottingham \\ ${ }^{b}$ Fiscal Policy Research Institute, Bangkok
}

\begin{abstract}
The Byrd Amendment, which redistributed antidumping duty revenue to import competing firms, has been declared an unauthorized "action against dumping". But does revenue redistribution dissuade dumping? Or is it a strategic trade policy? This paper uses a simple two-period duopoly model to evaluate these issues. An antidumping law provides an incentive for both firms to adjust sales so as to shift the dumping margin in their favor, and revenue redistribution strengthens this incentive for the filing firm. It is found that dumping is generally more prevalent and the dumping margin is larger with revenue redistribution, as a consequence. The profits of the filing (dumping) firm are generally, but not always, higher (lower). Consumers gain in one country and lose in the other, with the gainers and losers depending on the market size difference.
\end{abstract}

JEL Classification: F13, D43

Keywords: Antidumping, Byrd Amendment, strategic behavior

\section{Introduction}

In 2000, the United States Congress amended the US Antidumping Law so that the duty revenue was redistributed to those domestic producers who supported the petition that led to a finding of dumping, material injury to the domestic industry and imposition of an Antidumping (AD) duty. This legislation was formally known as the Continued

* Corresponding author: School of Economics, Sir Clive Granger Building, University of Nottingham, University Park, Nottingham NG7 2RD, UK. Tel: 441159515458; Fax: 441159514159; E-mail: rod.falvey@ nottingham.ac.uk. The authors are grateful to Jim Brander, a referee and participants at the 2007 APJAE Symposium on Strategic Trade Theory and Economic Development, the Midwest International Economics Group Meetings at Michigan State, the European Trade Study Group Conference in Dublin and a seminar at the University of Nottingham for comments. They acknowledge financial support from the Leverhulme Trust under Programme Grant F114/BE. 
Dumping and Subsidy Offset Act, but commonly referred to as the Byrd Amendment (BA). The stated objective in modifying the Law in this way was to give domestic firms harmed by dumped imports direct relief ${ }^{1}$ in addition to the benefits they indirectly received from the imposition of AD duties on their foreign competitors. Other countries objected, however, and in 2002 a World Trade Organization (WTO) Dispute Panel found such redistribution in violation of the WTO Antidumping provisions, an outcome confirmed by the WTO Appellate Body in $2003 .^{2}$ The Law was subsequently repealed, taking effect in October 2007.

Despite its seeming demise, the BA retains interest, particularly because of the incentives it provides to import-competing firms. Its role can be considered from two alternative policy perspectives. First, is transferring the duty revenue in this way likely to increase or reduce the incidence of dumping and the extent of the dumping margin? The WTO ruled against the BA on the grounds that it was an action "against" dumping not in accordance with General Agreement on Tariffs and Trade (GATT) / WTO AD Articles. Its action against dumping was inferred from the fact that the revenue was redistributed to the import-competing competitors of the dumpers. ${ }^{3}$ But is such an inference appropriate without investigation of the incentives that the BA provides to both parties and the likely market outcomes? Second, can revenue redistribution in this way be used to provide a strategic advantage to domestic firms in competition with foreign exporters? That is, can the BA act as a strategic trade policy, shifting profits in favor of domestic firms? Or, if an even broader objective is considered, does the BA lead to a new trading equilibrium in which the welfare of the redistributing country is higher?

This paper investigates these issues as a straightforward extension of a simple model that has been used elsewhere ${ }^{4}$ to investigate the links between dumping and market size. Considered in the previous paper were the incentives that the existence of an AD Law provides for strategic behavior on the part of duopolistic firms selling in each other's segmented markets. Firms had identical costs, but were located in countries with different market sizes (as a result of different maximum willingness to pay). In free trade the firm from the larger market dumped in the other market, providing incentives for both firms to manipulate their sales in the two markets to influence any future antidumping duty. It was shown that for small (large) differences in market size, the dumping (filing) firm's strategic actions dominate, and the dumping margin is reduced (increased) relative to free trade..$^{5}$

The incentives for strategic behavior that arise due to the presence of AD laws have received some attention in the literature. Typically this has involved consideration of two identical markets where dumping can be generated if say a monopolist in the home market competes with a foreign firm in the foreign market. The more competitive foreign

${ }^{1}$ The sums redistributed have been substantial - over US\$230 million in 2001; US\$330 million in 2002; US\$190 million in 2003; and US\$284 million in 2004 . See Collie and Vandenbussche (2006).

${ }^{2}$ Schmitz and Seale (2004) and Reynolds and Liebman (2006) provide details of the birth and death of the Byrd Amendment. Horn and Mavroidis (2005) analyze the WTO decisions.

\footnotetext{
${ }^{3}$ Horn and Mavroidis (2005) discuss these arguments in detail.

${ }^{4}$ In Falvey and Wittayarungruangsri (2006).

${ }^{5}$ These results are briefly reviewed in Section 3.1 below.
} 
market will then have the lower equilibrium price. If AD actions prevent price discrimination, the home firm exports less (Webb, 1992). In a two period version of the model, where dumping in the first period generates duties in the second, the home firm's first period exports fall to reduce the second period duty (Reitzes, 1993). The foreign firm will also expand its sales in order to increase the dumping margin, and the net effect could be an increase in the quantity sold in the foreign market in the first period (Fischer, 1992). Collie (2004) shows that, even if it could export it may be in the interest of the foreign firm to commit not to export to the home market, when the home firm's ability to price discriminate is curtailed by the foreign country's AD Law.

The BA has been subject to limited academic analysis to date. The issue of whether it will lead to higher duties has received some attention, but there has been no analysis of the implications of revenue redistribution for the strategic incentives of the firms during the dumping phase. ${ }^{6}$ Schmitz and Seale (2004) use a competitive partial equilibrium model to show that the "optimal anti-dumping tariff" (which maximizes the sum of producer surplus and revenue) exceeds the optimal tariff (which maximizes the sum of producer surplus, tariff revenue and consumer surplus), and the revenue maximizing tariff. Collie and Vandenbussche (2006) are interested in the possibility that a transfer of revenue could result in lower duties and higher welfare in the dumped market. Their context is a dutysetting government with a political economy objective function that puts a higher weight on producer interests (profits) than on consumer interests or tax revenue. They remind us that the welfare maximising tariff can exceed the revenue maximizing tariff in a Cournot oligopoly, and then show that transferring the duty revenue from the government to firms may result in a lower tariff, if this generates more revenue and the weight on producer interests in the government objective function exceeds a critical value. These results suggest that the duty outcomes will depend on market structure. Evenett (2006) notes the considerable bureaucratic discretion available in the calculation of the foreign market value (FMV) that import prices will be compared to in order to calculate duties owed after an $\mathrm{AD}$ order is put in place. He considers the extreme case where this value is determined independently of the dumping firm's pricing behavior or cost levels, and then examines how the BA provisions and uncertainty over the FMV act independently and jointly to determine the equilibrium outcomes under an $\mathrm{AD}$ order. He finds that sometimes dumping is eliminated, sometimes the profits of importing firms increase and sometimes even the total value of imports increase.

In outline the remainder of this paper is as follows. Section 2 sets up a model without AD legislation, solves for the equilibrium outcome, and identifies the conditions under which one firm dumps in the other country. Section 3 analyses the incentives AD policy, with and without the BA, provides for competing firms. It is shown that adding a redistributive mechanism strengthens the strategic incentives of the filing firm, particularly when the difference in market sizes is small. Now that firm always dominates the outcome;

\footnotetext{
${ }^{6}$ Empirical analysis suggests that firms will respond to the change in incentives. Reynolds and Liebman (2006) find links among firms' campaign contributions, Congressional behavior and firms' revenue receipts relating to the BA. Reynolds (2006), provides evidence of increases in AD filings (at least by firms familiar with $\mathrm{AD}$ procedures) and increases in the proportion of firms participating in $\mathrm{AD}$ actions after the $\mathrm{BA}$. The latter she attributes to a reduction in the free rider problem.
} 
hence the dumping margin is widened compared to free trade. The difference between the free trade dumping margin and those with $\mathrm{AD}$ and the revenue redistribution is greatest when the two markets are similar in size and becomes smaller as the market size difference grows. Section 4 considers the welfare effects, where it is found that the filing firm has higher profits (including the revenue) under the BA, except when the markets are similar in size or when the duty exceeds the revenue maximum. The dumping firm generally has lower profits. Whether consumers gain or lose from the BA depends on what happens to prices in their respective markets. Generally consumers in the dumper's domestic market gain (lose) where market size differences are relatively large (small), and the opposite holds for consumers in the filing firm's domestic market. The effects on aggregate welfare tend to reflect the consumer surplus effects. Section 5 concludes.

\section{Dumping in Free Trade}

In this section, a simple model is set up to show the conditions under which one firm dumps onto the other country. The effects of firm strategic actions on equilibrium outcomes will then be identified in the next section. Let there be two countries, home and foreign. Each has one firm. Both firms produce a homogeneous product and supply both markets. The markets are segmented so that there is no possibility of arbitraging by other economic agents. The firms are involved in a Cournot competition. For simplicity, both firms incur zero cost of production and there are no transport costs.

Linear demand is assumed in both countries. The demand functions for the home and foreign country are, respectively

$$
D=A-p \quad \text { and } \quad D^{*}=A^{*}-p^{*}
$$

where $D$ denotes home demand, $A$ denotes maximum willingness to pay and $p$ denotes the home price. The corresponding variables for the foreign country are indicated by an asterisk. Considering a representative period, the profits function for the two firms can be written as

$$
\begin{aligned}
& \pi=p x+p^{*} x^{*} \\
& \pi^{*}=p y+p^{*} y^{*}
\end{aligned}
$$

where $x(y)$ denotes home (foreign) firm output sold in the home market, and $x^{*}\left(y^{*}\right)$ denotes home (foreign) firm output sold in the foreign market. Differentiating (2) and (3) with respect to output quantities yields the following first order conditions:

$$
\frac{\partial \pi}{\partial x}=p-x=0 ; \frac{\partial \pi}{\partial x^{*}}=p^{*}-x^{*}=0 ; \frac{\partial \pi^{*}}{\partial y}=p-y=0 ; \frac{\partial \pi^{*}}{\partial y^{*}}=p^{*}-y^{*}=0
$$

These can in turn be solved for equilibrium outputs and prices:

$$
x=y=\frac{A}{3}=p ; \quad x^{*}=y^{*}=\frac{A^{*}}{3}=p^{*} \text {. }
$$


The profits for the home and foreign firms are then:

$$
\pi=\pi^{*}=\left[\frac{A}{3}\right]^{2}+\left[\frac{A^{*}}{3}\right]^{2}
$$

In free trade, both firms sell the same amount in each market (but more in the larger market) and earn the same total profits. As demand curves are both linear, with the same slopes (normalized to unity) but different intercepts, consumers in the country with the larger intercept are willing to pay a higher price for any given quantity and will purchase more at any given price. Given that markets are segmented, this market will have the higher price and larger total sales in the free trade equilibrium. It can therefore be referred to as the "larger market" (Gupta, 1999). Since the price is higher in this market, this generates the possibility that the firm from the larger market could be subject to a claim of dumping in the smaller market. The dumping margin (DM), in this case the price difference, will depend on the difference in market size between the two markets (e.g. in free trade $\left.D M=p-p^{*}=\left(A-A^{*}\right) / 3\right)$. Note that the two firms only differ in terms of their locations. The reason that dumping occurs is that national markets are segmented and it is profit maximizing for both firms to sell quantities that yield a higher price in the larger market.

In Figure 1, the first period price outcomes are plotted against the relative market size, with $P^{F}$ and $P^{* F}$ denoting home and foreign free trade prices respectively. Without loss of generality, it is assumed that the home market is larger and different values of $A\left(A \geq A^{*}\right)$ are considered for a fixed $A^{*}$. Then $P^{* F}$ does not change as $A$ increases (a horizontal line), while $P$ increases in the same proportion as $A$. The vertical distance between the two lines is the (free trade) dumping margin. The larger the difference in market size, the larger the dumping margin.

\section{Figure 1: First period prices in free trade $(F)$ and under anti-dumping with $(B)$ and without $(A)$ the Byrd Amendment}

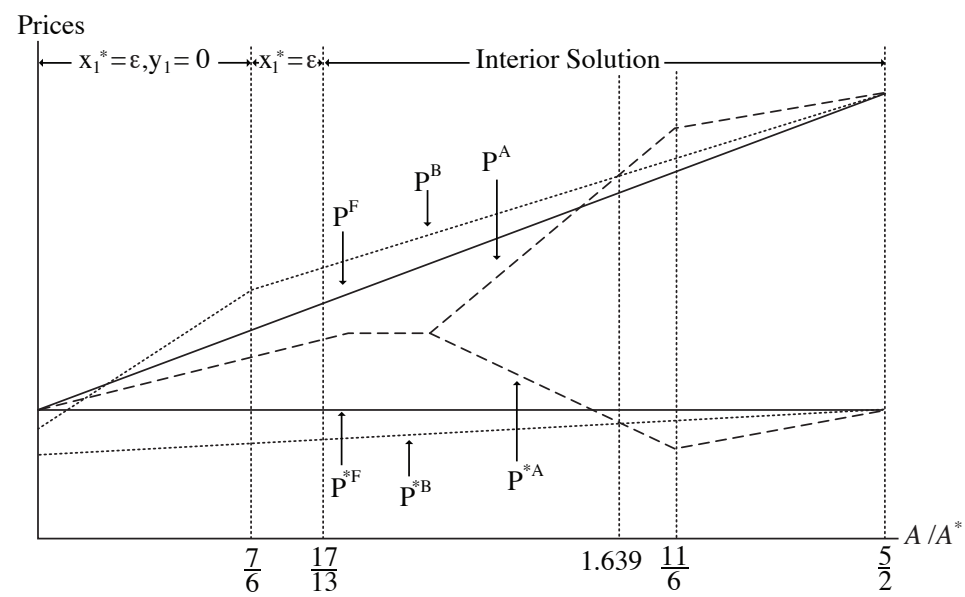




\section{Antidumping}

Now consider a dynamic version of the model. Two periods are assumed, and for simplicity, it is also assumed that the demand functions are as above in both periods and agents do not discount the future. The foreign country has in place AD legislation which provides that if the foreign firm files an $\mathrm{AD}$ petition and the home firm is found to have dumped in the present (period 1) it will be subject to a tax on its future (period 2) sales in the foreign market equal to the dumping margin (price difference) in the present. In addition, the foreign AD legislation may provide that the filing firm also receives any revenue collected from the AD duty (the Byrd Amendment). ${ }^{7}$ This paper's specific interest is in how this revenue redistribution affects the equilibrium outcomes.

First, the second period equilibrium when there is an $\mathrm{AD}$ duty of $t$ in place will be determinined. The second period profit-maximising problems of the two firms become, respectively

$$
\max _{x_{2}, x_{2}^{*} \pi_{2}=p_{2} x_{2}+\left[p_{2}^{*}-t\right] x_{2}^{*}}
$$

and

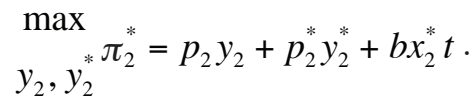

where $b$ is a parameter that takes the value 1 or 0 depending on whether the duty revenue is or is not redistributed to the foreign firm. These can be solved for the second-period outputs and prices as

$$
x_{2}=y_{2}=\frac{A}{3}=p_{2} ; \quad x_{2}^{*}=\frac{\left[A^{*}-2 t\right]}{3} ; y_{2}^{*}=\frac{\left[A^{*}+t\right]}{3}=p_{2}^{*} \text {. }
$$

While profits are

$$
\pi_{2}=\left[\frac{A}{3}\right]^{2}+\left[\frac{A^{*}-2 t}{3}\right]^{2} ; \quad \pi_{2}^{*}=\left[\frac{A}{3}\right]^{2}+\left[\frac{A^{*}+t}{3}\right]^{2}+b \frac{t\left[A^{*}-2 t\right]}{3}
$$

In the first period, both firms maximize their lifetime profits, taking into account the future duty and any redistribution of duty revenue. The firms understand that their sales in the current period can affect the future duty and therefore their profits in both. Since our primary objective is to illustrate, as simply as possible, the role of the BA in determining the equilibrium outcomes when both firms behave strategically, attention is

${ }^{7}$ In practice, the government transferred all revenue to the qualifying producers in proportion to their qualifying expenditures. These were quite broad, including manufacturing facilities, equipment, R\&D, health care benefits, pension benefits and working capital. 
restricted to pure strategy equilibria. This simplifies the analysis considerably, but still leaves some constraints to be dealt with. These relate to the minimum level of sales of the dumping firm in the first period, and the fact that the AD duty cannot be negative (i.e. a subsidy) nor act effectively above the prohibitive level. As noted above, the AD duty imposed on the home (dumping) firm's sales in the foreign market in period 2 is equal to any dumping margin (price differential) found in period 1. However, regardless of this price differential, no duty will be imposed if the home firm makes no sales in the foreign country in the first period. Thus there are two circumstances under which no duty will be levied in the second period: (i) the home firm exports in the first period but the dumping margin is zero; and (ii) there is a positive dumping margin in the first period but there are no home firm exports. This second circumstance has the complication of generating a discontinuity in our functions at $x_{1}^{*}=0$. As $x_{1}^{*}$ approaches zero from above a finite dumping margin applies, but this drops to zero when first period exports cease. It can be shown that abandoning the foreign market in the first period is not a pure-strategy equilibrium outcome for the home firm. But reducing "dumped" foreign sales to a minimal level in the first period will be an equilibrium outcome for some differences in market size. Encompassing this feature can be done by constraining $x_{1}^{*} \geq \varepsilon$ where $\varepsilon$ is some arbitrarily small positive amount. ${ }^{8}$ The requirement that the antidumping duty cannot be negative (i.e. cannot be a subsidy) can be captured by imposing the constraint that $p_{1}-p_{1}^{*} \geq 0$ on the "dumping" firm (since the filing firm has no incentive to take actions that reduce the duty).

The second period equilibrium outcomes are as in (7) above, and these solutions indicate a further constraint that must be imposed on the antidumping duty. These expressions for second period profits only apply if the antidumping duty is no greater than the prohibitive duty. From that point the home firm ceases to export in the second period, leaving the foreign firm to act as a monopolist in the foreign market. We can capture this requirement by imposing the constraint that $p_{1}-p_{1}^{*} \leq A^{*} / 2$ on the foreign firm (since the dumping firm has no incentive to take actions that raise the duty), and by restricting attention to the range of market sizes for which the free trade dumping margin would be less than the prohibitive duty (i.e. $A \leq 5 A^{*} / 2$ ) in the first instance. Since it is shown that the strategic actions of the firms lead to the prohibitive duty before this upper bound is reached, it is clear that the equilibrium will involve free trade in the first period generating a prohibitive duty in the second when $A>5 A^{*} / 2$.

The respective profit maximisation problems for the home and foreign firms are then

$$
\max _{x_{1}, x_{1}^{*}} \pi=p_{1} x_{1}+p_{1}^{*} x_{1}^{*}+\pi_{2} \quad \text { s.t. } x_{1}^{*} \geq \varepsilon \text { and } p_{1}-p_{1}^{*} \geq 0
$$

and

${ }^{8}$ Details are available in an Appendix from the authors. Note that setting exports to zero may be a best reply for the home firm to some strategies of the foreign firm, and there may be a mixed strategy Nash equilibrium that involves this firm abandoning the foreign market. 
$\underset{y_{1}, y_{1}^{*}}{\max } \pi^{*}=p_{1} y_{1}+p_{1}^{*} y_{1}^{*}+\pi_{2}^{*}$

s.t. $p_{1}-p_{1}^{*} \leq \frac{A^{*}}{2}$

The Lagrangean functions for the home and foreign firms are written as:

$$
\begin{aligned}
& \max _{x_{1}, x_{1}^{*}} \Pi=p_{1} x_{1}+p_{1}^{*} x_{1}^{*}+\left[\frac{A}{3}\right]^{2}+\left[\frac{A^{*}-2\left(p_{1}-p_{1}^{*}\right)}{3}\right]^{2}+\lambda\left[p_{1}-p_{1}^{*}\right]+\eta\left[x_{1}^{*}-\varepsilon\right] \\
& \max _{y_{1}, y_{1}^{*} \Pi^{*}=} p_{1} y_{1}+p_{1}^{*} y_{1}^{*}+\left[\frac{A}{3}\right]^{2}+\left[\frac{A+\left(p_{1}-p_{1}^{*}\right)}{3}\right]^{2} \\
& +b\left[\frac{\left(p_{1}-p_{1}^{*}\right)\left\{A^{*}-2\left(p_{1}-p_{1}^{*}\right)\right\}}{3}\right]+y\left[\frac{A^{*}}{2}-\left(p_{1}-p_{1}^{*}\right)\right]
\end{aligned}
$$

Differentiating (8) and (9) with respect to first-period outputs yield the following

$$
\begin{aligned}
& \frac{\partial \Pi}{\partial x_{1}}=\left\{p_{1}-x_{1}\right\}+\left\{\frac{4}{9}\left[A^{*}-2\left(p_{1}-p_{1}^{*}\right)\right]\right\}-\lambda \\
& \frac{\partial \Pi}{\partial x_{1}^{*}}=\left\{p_{1}^{*}-x_{1}^{*}\right\}-\left\{\frac{4}{9}\left[A^{*}-2\left(p_{1}-p_{1}^{*}\right)\right]\right\}+\lambda+\eta \\
& \frac{\partial \Pi^{*}}{\partial y_{1}}=\left\{p_{1}-y_{1}\right\}-\left\{\frac{2}{9}\left[A^{*}+\left(p_{1}-p_{1}^{*}\right)\right]\right\}-b\left\{\frac{1}{3}\left[A^{*}-4\left(p_{1}-p_{1}^{*}\right)\right]\right\}+y \\
& \frac{\partial \Pi^{*}}{\partial y_{1}^{*}}=p_{1}^{*}-y_{1}^{*}+\left\{\frac{2}{9}\left[A^{*}+\left(p_{1}-p_{1}^{*}\right)\right]\right\}+b\left\{\frac{1}{3}\left[A^{*}-4\left(p_{1}-p_{1}^{*}\right)\right]\right\}-y
\end{aligned}
$$

In the dumping firm's derivatives ((10) and (11)), the expressions on the right hand side are decomposed into two terms. The first is the corresponding expression in free trade. The second shows the incentive for strategic behavior produced by the existence of the foreign AD regulation. In the derivatives for the filing firm ((12) and (13)), the strategic incentives have been divided into two parts, the second of which only appears if the BA applies $(b=1)$. The presence of the BA has no direct impact on the dumping firm's incentive to behave strategically. ${ }^{9}$

Before obtaining the explicit solutions, it is informative to consider what these derivatives reveal about the firms' incentives and the strengths of those incentives when the

${ }^{9}$ In this sense the BA does not directly "dissuade the practice of dumping" as found in the WTO decisions. See Horn and Mavroidis (2005). 
threat of $\mathrm{AD}$ action exists. As long as the dumping margin is below the prohibitive level (i.e. $p_{1}-p_{1}^{*}<A^{*} / 2$ ) the home firm has an incentive to sell more in its domestic market and to export less. This incentive is stronger, the larger the second period sales (i.e. the smaller the AD duty). The strategic effects in (10) and (11) are of equal magnitude but opposite sign, indicating that rather than changing total output, the firm would adjust its sales between markets. ${ }^{10}$

For the foreign firm, the $\mathrm{AD}$ incentives can have two components. In the absence of the BA, the foreign firm also has an incentive to sell more in its domestic market and to export less. This incentive becomes larger as the duty increases and its second period profits increase. Adding the BA reinforces this incentive, up to the point where the implied duty reaches the revenue maximum (i.e. $p_{1}-p_{1}^{*}=A^{*} / 4$ ). From that point on the presence of the BA reduces the strategic incentive of the foreign firm. Again note that, as for the home firm, the strategic effects in (12) and (13) are of equal magnitude but opposite sign, indicating a tendency to switch sales rather than changing total output.

Each firm's strategic action counters the other's. Which firm's behavior dominates depends on the relative market size. If it is supposed that the BA does not apply and the free-trade dumping margin $\left(p_{1}-p_{1}^{*}=\left[A-A^{*}\right] / 3\right)$ is substituted into the strategic incentives for sales in the home market, we find that, for the home firm

$$
\frac{4}{9}\left[A^{*}-2\left(p_{1}-p_{1}^{*}\right)\right]=\frac{4}{27}\left[5 A^{*}-2 A\right]
$$

while for the foreign firm

$$
\frac{2}{9}\left[A^{*}+\left(p_{1}-p_{1}^{*}\right)\right]=\frac{2}{27}\left[2 A^{*}+A\right] \text {. }
$$

As noted above, given the size of the foreign market, increases in the size of the home market increase the free trade dumping margin, which reduces the strategic incentive of the home firm, but strengthens that of the foreign firm. When $A=8 A^{*} / 5$, the firms' strategic incentives are offsetting. This suggests that, for small differences in market sizes, the home firm's strategic actions should dominate the equilibrium outcome, implying a smaller dumping margin than in free trade. For larger market size differences, it is likely that the foreign firm's actions dominate, leading to a larger dumping margin than in free trade.

When the BA applies, the two parts of the strategic incentive of the foreign firm are combined, resulting in:

$$
\begin{aligned}
& \frac{\partial \Pi^{*}}{\partial y_{1}}=\left\{p_{1}-y_{1}\right\}-\left\{\frac{5}{9}\left[A^{*}-2\left(p_{1}-p_{1}^{*}\right)\right]\right\}+y \\
& \frac{\partial \Pi^{*}}{\partial y_{1}^{*}}=\left\{p_{1}^{*}-y_{1}^{*}\right\}+\left\{\frac{5}{9}\left[A^{*}-2\left(p_{1}-p_{1}^{*}\right)\right]\right\}-y
\end{aligned}
$$

\footnotetext{
${ }^{10}$ This is true as long as exports are not at their minimum level (i.e. as long as $x_{1}^{*}>\varepsilon$ and $\eta=0$ ).
} 
A comparison of (14) and (15) with (10) and (11) is particularly revealing of the strategic incentives facing the two firms. They are opposite in sign and that of the foreign firm is stronger over the entire range of non-prohibitive dumping margins. It is expected that this dominance by the foreign firm's strategic actions will be reflected in a higher dumping margin in the first period equilibrium. But note that both firms' strategic incentives fall as the difference in market sizes becomes larger.

Below are explicit solutions for these two cases.

\section{[A] Antidumping without the Byrd Amendment.}

The first period price outcomes $\left(P^{A}, P^{* A}\right)$ are shown in Figure 1, and the full solutions are shown in Appendix Table 1. As expected, for small differences in market size, the dumping firm's actions dominate the outcomes. If $A<25 A^{*} / 18$ this results in temporary market integration and a zero dumping margin. Moderated dumping, where there is a positive dumping margin but it is smaller than in free trade, is observed when $25 A^{*} / 18$ $<A<8 A^{*} / 5$. But after this point the filing firm's strategic actions begin to dominate resulting in aggravated dumping where the dumping margin is higher than in free trade. The duty becomes prohibitive when $A=11 A^{*} / 6$.

\section{[B] Antidumping with the Byrd Amendment.}

As seen above, the addition of the BA has no effect on the strategic incentives faced by the home firm. But the behavior of the foreign firm will be affected by having any duty revenue redistributed in its favor. ${ }^{11}$ The first period prices are indicated by $P^{B}$, $P^{* B}$ in Figure 1 and the full solutions are provided in Appendix Table 2. ${ }^{12}$ If the Byrd Amendment applies, then the foreign firm's strategic incentives dominate for all market size differences. The result is an increased dumping margin, relative to free trade, though the difference declines as the market size difference becomes larger. The comparison with and without the BA is also revealing. If revenue is not redistributed, then the AD Law actually eliminates dumping for small market size differences and moderates it over an additional range. It is only when the market size difference becomes so large that the foreign firm's strategic incentives dominate that the AD Law leads to an increased dumping margin. Interestingly this pattern is reversed once the BA is added. Then there is no range of temporary market integration or moderated dumping. But once the difference in market sizes is large enough, leading to the range where the foreign firm's strategic actions dominate even without the BA, then the revenue redistribution will result in a reduced dumping margin as the decline in revenue as the duty increases tempers the foreign firm's strategic actions. Only over this range can the BA be said to "discourage" dumping, even then only relative to the outcome without revenue redistribution and

\footnotetext{
${ }^{11}$ Revenue is increasing in the duty until $t=A^{*} / 4$, while second period profits are always increasing until the duty becomes prohibitive. The total benefits to the foreign firm are increasing in the duty all the way to the prohibitive level.

${ }^{12}$ There are ranges of market size differences where the constraints specified in (8) and (9) apply to the relevant firms, as indicated in Appendix Table 2. The most striking outcome is that when market sizes are very similar, the equilibrium under the Byrd Amendment results in prices in both markets being lower than in free trade. This is a heavily constrained equilibrium, however, with almost no trade (i.e. $x_{1}^{*}=\varepsilon$ and $y_{1}=0$ ).
} 
because of the incentive it provides to the foreign firm - not the dumper. The dumping margin is always higher than in free trade.

\section{Welfare effects}

It seems that revenue redistribution is unlikely to reduce instances of dumping, and indeed may increase or reduce the dumping margin, depending on relative market sizes. The more similar the markets are in size, the more likely the BA is to lead to an outcome of aggravated dumping, because of the strategic behavior it induces. Hence, as noted above, it is difficult to interpret the BA as an action against dumping in this context. But how does it fare as a strategic trade policy? Does the BA "punish" the dumping firm, in the sense that its profits are lower than they otherwise would be? Does it "support" the filing firm through the same channel? Since the strategic behavior induced by the $\mathrm{AD}$ legislation in either form has quite dramatic effects on equilibrium prices in the two markets in the first period, the implications for consumer surplus and aggregate welfare are also likely to be significant. In the interests of brevity, attention is restricted to the broad welfare outcomes rather than attempting a comprehensive discussion of each of the regimes identified in Appendix Tables 1 and 2. Profits, consumer surplus and welfare are continuous, though nonlinear, functions of market size differences, where the exact functional relationship depends on the regime in operation.

\subsection{Profits}

First the foreign firm's profits will be considered, since political economy considerations suggest that supporting these profits is likely to be an important objective of the AD Law and any amendments to it. Since the BA gives the foreign firm the duty revenue in the second period, one might expect that its profits in that period at least are higher with the BA than without. While this is true for small differences in market size, recall that these same revenue considerations induce the foreign firm to be less aggressive in the first period for market size differences where the duty would already be significant, implying a lower equilibrium duty and in fact lower foreign firm profits in the second period once the market difference becomes large enough. In the first period the foreign firm is induced to switch sales to the foreign market. For small market size differences the BA induces the foreign firm to act so aggressively as to drive up an otherwise small (or indeed nonexistent) dumping margin, reducing the foreign market price and its first period profits in the process. But when market size differences become sufficiently large its aggression is tempered. The net results for the foreign firm's profits are shown in Figure 2. Its profits are higher under the BA, except where markets are very similar in size (and prices in both markets are lower in the first period) and where market size differences are large. 


\section{Figure 2: Differences in home firm's and foreign firm's profits}

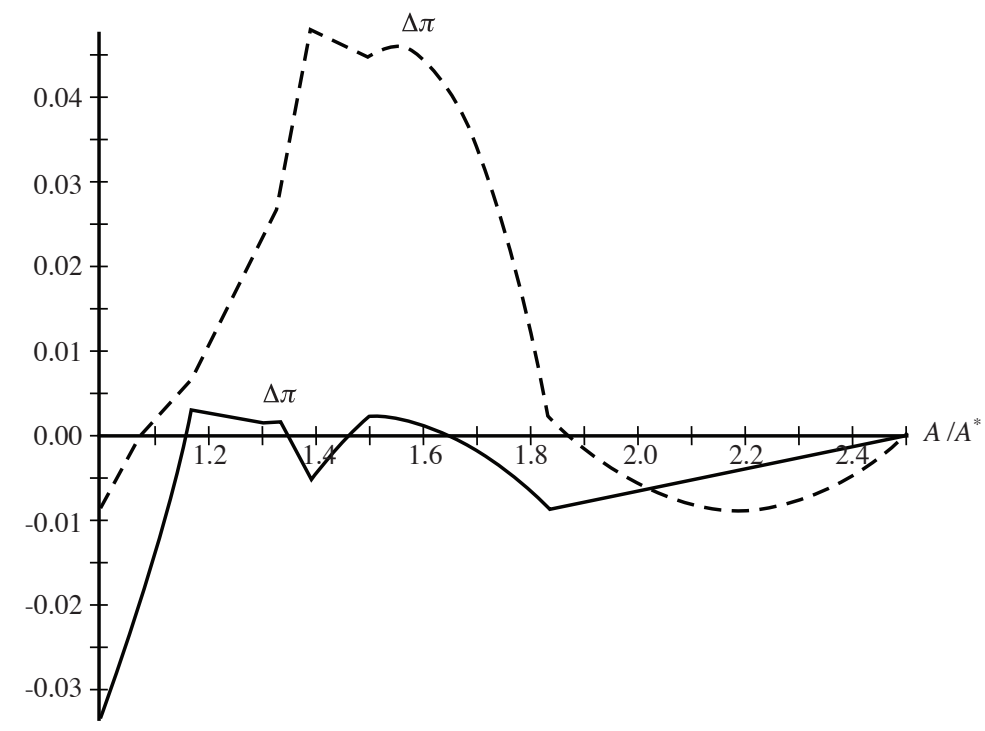

The difference in outcomes for the home firm's profits is also shown in Figure 2. Again this reflects the combination of outcomes from the two periods. Recall that the home firm has been induced to switch sales to its domestic market. The home firm's profits are lower in the first period under the BA for small market size differences and for large market size differences, because in each case the price in the home market is lower under the BA. Its second period profits are lower under the BA, except for large market size differences, where duty revenue considerations induce the foreign firm to act less aggressively, so that the duty is lower under the BA and the home firm's profits in the foreign market are higher. Combining these gives the outcomes shown in Figure 2. The home firm is worse off under the BA for small and large market size differences (in the latter case the loss of first period profits outweighs the gain in the second period). But there is an "interrupted" intermediate range where the home firm has slightly higher profits under the BA. These correspond to regimes where the gain in the first period outweighs the loss in the second. ${ }^{13}$

Overall, both firms lose under the BA for small and large market size differences. The foreign firm gains in the intermediate range, where the home firm has ranges of (small) gains and losses. There are market size differences for which both firms gain, but in general the foreign firm is more likely to gain and has the larger gains. The scope for the revenue redistribution to act as a strategic trade policy supporting the domestic firm is clear.

${ }^{13}$ The difference in the home firm's profits in each of the periods are plotted in Appendix Figure A1. There are clear losses in both periods for small market size differences, and for larger differences, gains in one period and losses in the other. 


\subsection{Consumer Surplus}

The general pattern of differences in consumer surplus in the first period can be inferred from the price schedules in Figure 1. Foreign consumers face lower prices under the BA as long as market size differences are relatively small, and higher prices if market size differences are larger. Conversely in the second period, foreign consumers face higher prices when market sizes are relatively small, and lower prices when they are large under the BA. The net result, shown in Figure 3 shows foreign consumer surplus is higher under the BA as long as markets are similar in size and is lower otherwise. The differences in the first period dominate.

\section{Figure 3: Differences in home and foreign consumer surplus}



Home consumers are unaffected in the second period. The price differences in Figure 1 show that home consumers face lower prices under the BA when market sizes are very similar and when they are very different. In the intermediate range they face higher prices. The difference in consumer surplus reflects this. Overall both groups of consumers gain if market size differences are small and one group gains and the other loses when market size differences are larger.

\subsection{Aggregate Welfare}

Aggregate welfare in the foreign country is the sum of foreign consumer surplus, foreign firm profits and duty revenue (where the latter two are combined when the BA is in effect). The difference in foreign welfare is shown in Figure 4. As a strategic trade policy aimed at improving aggregate welfare, adding revenue redistribution to an existing 
AD law will be successful as long as the markets are not too different in size (when both foreign firm profits and consumer surplus are lower). Indeed, a comparison of Figures 2 and 4 shows an intermediate range of market sizes differences for which both foreign firm profits and foreign welfare are higher under the BA. The opposite holds for aggregate home welfare, which is higher (lower) under the BA when the foreign welfare is lower (higher). From an aggregate welfare perspective the trading partners clearly have opposing interests in whether revenue should be redistributed.

\section{Figure 4: Differences in home and foreign aggregate welfare}

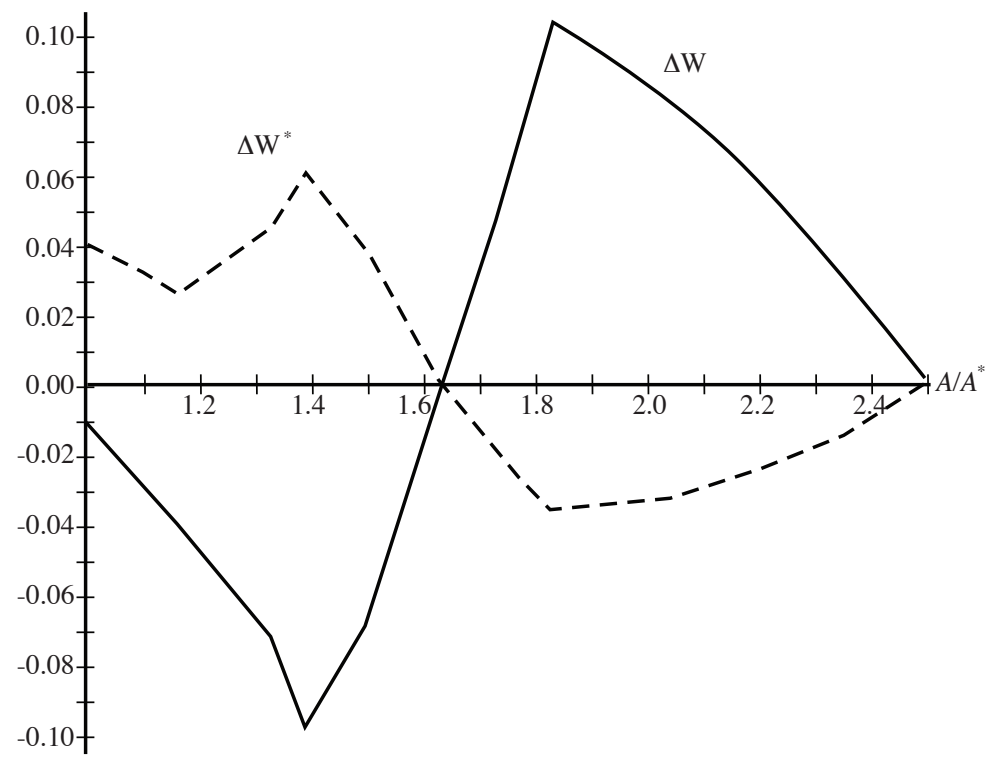

\section{Summary and Conclusions}

This paper has examined the effects of revenue redistribution on the behavior of firms engaged in an $\mathrm{AD}$ case, and the consequences for the market outcomes. This was done by setting up a simple model of two segmented national markets, differing only in terms of market size. There were two firms, one located in each country, producing identical goods and selling in both markets. The free trade equilibrium then has the firm located in the country with a larger market dumping onto the other. When the AD policy was implemented, the equilibrium outcome depended on the difference in market sizes. The case without the BA was considered first. The two firms had different incentives. The dumping firm attempted to reduce the dumping margin by switching sales between national markets while the other firm performed the opposite action. The outcome was dominated by the dumping firm when the market size difference was small, and a reduced dumping margin relative to free trade was seen. But when the market sizes differed more, it was the other firm that dominated the outcome and then the dumping margin was increased. 
The addition of revenue redistribution (via the Byrd Amendment) in the second period influenced the incentives facing the filing firm in the first period, but those of the dumping firm were unchanged. ${ }^{14}$ Now the strategic behavior of the filing firm always dominated the outcome. This resulted in a higher dumping margin relative to free trade, and relative to AD without the BA, except for large differences in market size where revenue considerations lead to a smaller dumping margin (but still greater than in free trade). Taking into account the strategic incentives that the BA provides, it can be concluded that it is likely to increase the incidence of dumping and the extent of the dumping margin. The best one can claim is that, compared to the situation in which the duty revenue is not redistributed, the duty is less likely to be prohibitive.

The welfare effects of revenue redistribution in this model are an aggregate of changes in the two periods. In broad terms, the foreign firm sacrifices first period profits to increase the dumping margin, and then benefits from higher profits and the revenue in the second period. The BA gives higher profits for the foreign firm, except where market size differences are small (and its quest for a higher dumping margin results in lower prices in both markets in the first period), and where market size differences are relatively large (and it becomes more interested in maintaining its duty revenue income). For the remainder of this range, revenue redistribution can act as a strategic trade policy, shifting profits to the domestic firm. The dumping firm has lower profits under the BA, except for an intermediate range of market size differences where it can have small gains. It would generally be expected that exporting firms would oppose revenue redistribution of this form.

Consumers in the two countries have generally opposing interests, except where the market size difference is small and consumers in both countries gain from lower prices. Otherwise home consumers prefer the BA when market size differences are larger and their first period prices are lower, and foreign consumers prefer the BA when market size differences are smaller and their first period prices are lower. When these profit and consumer surplus effects are combined, the effects of the BA on aggregate welfare are clear cut. The foreign country gains if market size differences are small and the home country gains if market size differences are large.

Clearly the BA has been examined in a very specific context. The intent has been to isolate and to highlight the strong incentive effect that revenue redistribution implies for the filing firm and the consequences of this for the equilibrium outcomes. Redistributing the $\mathrm{AD}$ duty revenue to the import-competing firms reinforces its interest that dumping be found and that the dumping margin is large, at least up to the revenue maximizing level. It acts more aggressively as a consequence, leading to a larger dumping margin in the first period, through lower foreign prices and higher home prices (except where market size differences are small and both prices fall). The foreign country gains and the home country loses. Once the duty becomes larger, however, revenue redistribution leads the importcompeting firm to act less aggressively than otherwise, leading to a smaller dumping margin and higher prices in the foreign country and lower prices at home than otherwise. The home country gains and the foreign country loses. But dumping continues.

${ }^{14}$ Thus the BA does not directly dissuade dumping as noted above. An interesting extension of this work would be for the home government to treat the BA payments to the foreign firm as a subsidy and to impose countervailing duties on that firm's exports to the home market in the second period. 
Does revenue redistribution "dissuade the practice of dumping"? Clearly not in this case. While different models might lead to different outcomes, the incentive effects that are highlighted will remain present even if in a weakened form. To obtain a significantly different outcome, the revenue redistribution would also need to directly affect the strategic incentives of the dumping firm. Such might be the case, for example, in a model which involved an initial R\&D or investment stage that served to determine firms' production costs, raising the possibility that, in certain circumstances, revenue redistribution might dissuade dumping in the longer term. Investigating such possibilities is work for the future.

\section{References}

Collie, D., 2004, “Anti-dumping regulations: anti-competitive and anti-export”, mimeo, Cardiff Business School.

Collie, D. and H. Vandenbussche, 2006, "Tariffs and the Byrd Amendment" European Journal of Political Economy, 22(3), 750-758.

Evenett, S., 2006, "The Simple Analytics of US Antidumping Orders: Bureaucratic Discretion, Anti-importer Bias, and the Byrd Amendment" European Journal of Political Economy, 22(3), 732-749.

Falvey, R. and S. Wittayarungruangsri, 2006, "Market Size and Antidumping in Duopolistic Competition” European Journal of Political Economy, 22(3), 771-786.

Fischer, R., 1992, "Endogenous probability of protection and firm behaviour”, Journal of International Economics 32, 149-63.

Gupta, P., 1999, "Why do firms pay antidumping duty?" International Monetary Fund Working Paper WP/99/166, Washington DC.

Horn, H. and P.C. Mavroidis, 2005, "United States - Continued Dumping and Subsidy Offset Act of 2000", World Trade Review 4(3), 525-550.

Reitzes, J., 1993, “Antidumping policy”, International Economic Review 34, 745-763.

Reynolds, K., 2006, "Subsidizing Rent-Seeking: Antidumping Protection and the Byrd Amendment", Journal of International Economics 70, 490-502.

Reynolds, K. and B. Liebman, 2006, “The Returns to Rent-Seeking: Campaign Contributions, Firm Subsidies and the Byrd Amendment" Canadian Journal of Economics 39(6), 1345-1369.

Schmitz, T.G. and J.L. Seale, Jr., 2004, “Countervailing Duties, Antidumping Tariffs and the Byrd Amendment: A Welfare Analysis", International Journal of Applied Economics 1(1), 65-80.

Webb, M., 1992, "The ambiguous consequences of anti-dumping laws", Economic Inquiry 30, 437-448. 


\section{Appendix}

Table 1

Both Firms Behave Strategically (No Byrd Amendment)

\begin{tabular}{|c|c|c|c|c|c|c|}
\hline & $\begin{array}{c}\text { Temporary } \\
\text { Market } \\
\text { Integration }\end{array}$ & $\begin{array}{c}\text { Temporary } \\
\text { Market } \\
\text { Integration } \\
{\left[x_{1}^{*}=\varepsilon\right]}\end{array}$ & $\begin{array}{c}\text { Moderated } \\
\text { Dumping } \\
{\left[x_{1}^{*}=\varepsilon\right]}\end{array}$ & $\begin{array}{c}\text { Moderated } \\
\text { Dumping }\end{array}$ & $\begin{array}{l}\text { Prohibitive } \\
\text { Dumping }\end{array}$ & $\begin{array}{l}\text { Uncon- } \\
\text { strained } \\
\text { Dumping }\end{array}$ \\
\hline$A / A^{*}$ & {$\left[1,{ }^{4} / 3\right]$} & {$[4 / 3,25 / 18]$} & {$[25 / 18,3 / 2]$} & {$[3 / 2,11 / 6]$} & {$[11 / 6,5 / 2]$} & {$[5 / 2, \infty]$} \\
\hline$P_{1}$ & $\frac{A+A^{*}}{6}$ & $\frac{7 A^{*}}{18}$ & $\frac{24 A-17 A^{*}}{42}$ & $\frac{17 A-16 A^{*}}{21}$ & $\frac{2 A+5 A^{*}}{12}$ & $\frac{A}{3}$ \\
\hline$P_{1}^{*}$ & $\frac{A+A^{*}}{6}$ & $\frac{7 A^{*}}{18}$ & $\frac{41 A^{*}-6 A}{84}$ & $\frac{23 A^{*}-10 A}{21}$ & $\frac{2 A-A^{*}}{12}$ & $\frac{A^{*}}{3}$ \\
\hline$P_{1}-P_{1}^{*}$ & 0 & 0 & $\frac{18 A-25 A^{*}}{28}$ & $\frac{9 A-13 A^{*}}{7}$ & $\frac{A^{*}}{2}$ & $\frac{A-A^{*}}{3}$ \\
\hline$x_{1}$ & $\frac{6 A-A^{*}}{9}$ & $\frac{9 A-5 A^{*}}{9}$ & $\frac{5 A^{*}}{6}$ & $\frac{4 A^{*}-A}{3}$ & $\frac{2 A+5 A^{*}}{12}$ & $\frac{A}{3}$ \\
\hline$x_{1}^{*}$ & $\frac{4 A^{*}-3 A}{9}$ & $\varepsilon$ & $\varepsilon$ & $\frac{2 A-3 A^{*}}{3}$ & $\frac{2 A-A^{*}}{12}$ & $\frac{A^{*}}{3}$ \\
\hline$y_{1}$ & $\frac{3 A-A^{*}}{18}$ & $\frac{A^{*}}{6}$ & $\frac{3 A-3 A^{*}}{7}$ & $\frac{11 A-12 A^{*}}{21}$ & $\frac{4 A-5 A^{*}}{6}$ & $\frac{A}{3}$ \\
\hline$y_{1}^{*}$ & $\frac{3 A+7 A^{*}}{18}$ & $\frac{11 A^{*}}{18}$ & $\frac{6 A+43 A^{*}}{84}$ & $\frac{19 A^{*}-4 A}{21}$ & $\frac{7 A^{*}-2 A}{6}$ & $\frac{A^{*}}{3}$ \\
\hline$P_{2}^{*}$ & $\frac{A^{*}}{3}$ & $\frac{A^{*}}{3}$ & $\frac{6 A+A^{*}}{28}$ & $\frac{3 A-2 A^{*}}{7}$ & $\frac{A^{*}}{2}$ & $\frac{A^{*}}{2}$ \\
\hline$x_{2}^{*}$ & $\frac{A^{*}}{3}$ & $\frac{A^{*}}{3}$ & $\frac{13 A^{*}-6 A}{14}$ & $\frac{11 A^{*}-6 A}{7}$ & 0 & 0 \\
\hline$y_{2}^{*}$ & $\frac{A^{*}}{3}$ & $\frac{A^{*}}{3}$ & $\frac{6 A+A^{*}}{28}$ & $\frac{3 A-2 A^{*}}{7}$ & $\frac{A^{*}}{2}$ & $\frac{A^{*}}{2}$ \\
\hline$\lambda$ & $\frac{13 A^{*}-9 A}{18}$ & $\frac{25 A^{*}-18 A}{18}$ & 0 & 0 & 0 & 0 \\
\hline$\eta$ & 0 & $\frac{3 A-4 A^{*}}{3}$ & $\frac{3 A^{*}-2 A}{4}$ & 0 & 0 & 0 \\
\hline$\gamma$ & 0 & 0 & 0 & 0 & $\frac{6 A-11 A^{*}}{12}$ & NA \\
\hline
\end{tabular}

Note: For convenience $\varepsilon \approx 0$ is used in this Table, except for where $x_{1}^{*}=\varepsilon$ 
Table 2

Both Firms Behave Strategically (With Byrd Amendment)

\begin{tabular}{|c|c|c|c|c|}
\hline & $\begin{array}{l}\text { Aggravated Dumping } \\
\qquad\left[x_{1}^{*}=\varepsilon, y_{1}=0\right]\end{array}$ & $\begin{array}{l}\text { Agggravated Dumping } \\
\qquad\left[x_{1}^{*}=\varepsilon\right]\end{array}$ & $\begin{array}{l}\text { Agggravated } \\
\text { Dumping }\end{array}$ & $\begin{array}{l}\text { Unconstrained } \\
\text { Dumping }\end{array}$ \\
\hline$A / A^{*}$ & {$\left[1,{ }^{7} / 6\right]$} & {$\left[7 / 6,{ }^{17} / 13\right]$} & {$[17 / 13,5 / 2]$} & {$[5 / 2, \infty]$} \\
\hline \multirow[t]{2}{*}{$P_{1}$} & $\underline{7 A-4 A^{*}}$ & $\underline{7 A+A^{*}}$ & $29 A+5 A^{*}$ & $\underline{A}$ \\
\hline & 10 & 22 & 93 & $\overline{3}$ \\
\hline \multirow{2}{*}{$P_{1}^{*}$} & $\underline{A}$ & $\underline{5 A+7 A^{*}}$ & $2 A+26 A^{*}$ & $A^{*}$ \\
\hline & $\overline{4}$ & 44 & 93 & 3 \\
\hline \multirow{2}{*}{$P_{1}-P_{1}^{*}$} & $\underline{9 A-8 A^{*}}$ & $\underline{9 A-5 A^{*}}$ & $\underline{9 A-7 A^{*}}$ & $\underline{A-A^{*}}$ \\
\hline & 20 & 44 & 31 & 3 \\
\hline \multirow[t]{2}{*}{$x_{1}$} & $\underline{3 A+4 A^{*}}$ & $\underline{3 A+13 A^{*}}$ & $65 A^{*}+5 A$ & $\underline{A}$ \\
\hline & 10 & 22 & 93 & $\overline{3}$ \\
\hline \multirow[t]{2}{*}{$x_{1}^{*}$} & $\varepsilon$ & $\varepsilon$ & $26 A-34 A^{*}$ & $A^{*}$ \\
\hline & & & 93 & 3 \\
\hline \multirow{2}{*}{$y_{1}$} & 0 & $\underline{6 A-7 A^{*}}$ & $\underline{59 A-70 A^{*}}$ & $\underline{A}$ \\
\hline & & 11 & 93 & 3 \\
\hline \multirow[t]{2}{*}{$y_{1}^{*}$} & $4 A^{*}-A$ & $37 A^{*}-5 A$ & $101 A^{*}-28 A$ & $A^{*}$ \\
\hline & 4 & 44 & 93 & 3 \\
\hline \multirow[t]{2}{*}{$P_{2}^{*}$} & $\underline{3 A+4 A^{*}}$ & $13 A^{*}+3 A$ & $\underline{3 A+8 A^{*}}$ & $A^{*}$ \\
\hline & 20 & 44 & 31 & 2 \\
\hline \multirow{2}{*}{$x_{2}^{*}$} & $6 A^{*}-3 A$ & $9 A^{*}-3 A$ & $15 A^{*}-6 A$ & 0 \\
\hline & 10 & 22 & 31 & \\
\hline \multirow[t]{2}{*}{$y_{2}^{*}$} & $\underline{3 A+4 A^{*}}$ & $3 A+13 A^{*}$ & $\underline{3 A+8 A^{*}}$ & $A^{*}$ \\
\hline & 20 & 44 & 31 & 2 \\
\hline \multirow[t]{2}{*}{$\eta$} & $16 A^{*}-13 A$ & $17 A^{*}-13 A$ & 0 & 0 \\
\hline & 20 & 44 & & \\
\hline
\end{tabular}

Note: For convenience $\varepsilon \approx 0$ is used in this Table, except for where $x_{1}^{*}=\varepsilon$ 
Asia-Pacific Journal of Accounting \& Economics 14 (2007) 259-277

Figure A1: Differences in home firm's profits in periods 1 and 2.



